\title{
Self-Regulated Learning in Digital Era
}

\author{
Melani Aprianti, M.Psi., Psikolog Fakultas \\ Psikologi, Universitas Mercu Buana Email: \\ melani.aprianti@mercubuana.ac.id
}

Tri Widiatmini, S.Psi

Fakultas Psikologi, Universitas Mercu Buana

Email: widi.tri.91@gmail.com

\begin{abstract}
Information and communication technology in Indonesia has grown rapidly. One of the indications that support this statement is a data from the Ministry of Communications and Information which shows that internet users in Indonesia is ranked sixth in the category of countries with the largest number of internet users in the world from 2013 to 2018. The main population of information technology user is dominated by students, both in school and in college. Beside the positive impacts, this also brings negative influences $\mathrm{n}$ learning, because uncontrolled usage of information and communication technology can lead to addiction. As a college student, in addition to exposure to the negative impacts of technological development, they also have their own difficulties, whether they are working or not working while studying. Therefore, they need the ability of self regulated learning to achieve their academic goals. This research's main purpose is to identify the description of self regulated learning, more spesifically the equation and differences of self regulated learning on working college students and non-working college students. This research is a quantitative research, performed by taking samples of active students who enrolled in the Faculty of Psychology, X University. We used 86 non-working college students and 91 working college students as samples. The results obtained from this study shows that the self regulated learning capability of non-working college students is higher than the self regulated learning capability of working college students. Furthermore, although the level of metacognition and behavior dimensions of working college students are higher compared to non-working students, the motivation dimension of non-working students is higher than working students.
\end{abstract}

Keywords: Self-Regulated Learning, Information and Communication Technology, College Students. 


\section{INTRODUCTION}

The development of information and communication technology, more commonly known by the term Information and Communication Technology (ICT) has branched to other aspects of life, such as education and teaching (Afrianingrum dan Mulyono, 2012). The improvement of information and communication technology is marked by the increase of gadget usage or other equipments that can be easily connected to the internet. Data from the Ministry of Communication and Informatics (Kementerian Komunikasi dan Informatika/Kominfo) shows that internet users in Indonesia ranked sixth among all countries in the world. Indonesia is ranked sixth in the world in the category of most internet users in the period of 2013 to 2018. In 2013, the amount of internet users in Indonesia is estimated at 72.8 million people. In 2014, that number grew to 83.7 million people. In 2015, the number of internet users in Indonesia grew to 93.4 million people. In 2016, that number grew to 102.8 million people. In the year 2017, internet users in Indonesia is predicted to be 112.6 million people. Furthermore, by 2018, that number is predicted to continue growing, reaching an estimated 123 million people (Ministry of Communication and Informatics, accessed on September 20th, 2017).

Aside from that, a survey performed by the Association of Indonesian Network Internet Provider (Asosiasi Penyelenggara Jaringan Internet Indonesia/APJII) shows that more than a half of Indonesian citizen has been connected to the internet. During the year 2017, it was discovered that 143.26 million people has been connected to the internet, out of the total population in Indonesia, which is 262 million. The result also shows that, on average, internet users in Indonesia use handheld devices. The device used most is smartphone, with $44.16 \%$ of the total users, while computer/laptop usage is $4.49 \%$, and $39.28 \%$ use both. In terms of age, the largest number of internet users, with $49.52 \%$ of all users, are from the 19-34 age group. $43.89 \%$ of internet users accessed the internet for a minimum of 1-3 hours, $29.63 \%$ of them accessed it for 4-7 hours and $26.89 \%$ use the internet for more than 7 hours a day (Melani \& Eliya, 2018).

This condition definitely affects the learning process. One of its effect is the high amount of overusage of media and internet, to the point of addiction. Amongst them are internet addiction, gadget addiction, and online game addiction. Of course, these addictions can negatively affect study, such as for those going 
to college. Online game addiction doesn't just happen to children, the majority of sufferers are teenagers, including college students (Febriani, 2012). Online game addiction suffered by college students can cause a decline in academic achievement, due to the large amount of time they spent playing that it cut into their study time, even causing them to skip class (Liu \& Kuo, 2007). Theresia (2012) discovered that the higher the level of a college student's addiction to online game, the lower his/her academic achievement is. Other than online game, one other effect of the development of information technology is the growth of social media usage. A research by Rismana, Normelani, and Adyatama (2016) found that there is a negative effect and strong association between usage of social media and study motivation, which means that the higher the level of social media usage, the lower the study motivation is.

The main actor that pushed the development of information technology is dominated by students, both from school and college (Wijayanto, 2014). Learning in college is different with learning in middle school, students are demanded to be more independent, active, mature, able to take the correct decisions in regard to their studies, and able to explore the potentials they possess (Supriyanto, 2015). Aside from the temptation of advanced technologies, such as internet, that can cause addiction, learning in college also has its own difficulties. Arjanggi and Suprihatin (2010) performed a preliminary survey and discovered that some college students found difficulties in keeping up with the learning activites in college. Said survey shows that 4.2 percent of college students possesses a below average academic self efficacy;

20.8 percent of them experienced anxiety when facing test; 10.4 percent experienced a lack of interest towards the learning process in college.;

6.3 percent of college students have problem with cognitive strategies used in the learning process; and 20.8 percent of them faced difficulties with metacognitive regulation in learning (Supriyanto, 2015).

As a college student, who has many tasks and activities to do, it takes a good time management skill to ensure that all the activities can be performed well. But in reality, not all college students possess a good time management skill. The problem that many colleges face is that the amounts of graduates are not proportional with the number of students enrolling (Akmal, 2013).

To achive success in study takes a good studying regulation. Especially at the college level; where students are demanded to 
learn independently and actively, the ability to identify a suitable study strategy, to overcome difficulties in the studying process and to regulate themselves is very important. The ability to regulate oneself independently in studying is known as self-regulated learning. Zimmerman (1989) defined self regulated learning as a level where participants actively incorporate metacognition, motivation, and behavior in the learning process. Self regulated learning can also be defined as a form of individual study by relying on their personal studying motivation, autonomically developing their dimensions (cognition, metacognition, and behavior), and monitoring the progress in their study (Baumert in Latipah, 2010).

As working students, students in the regular class no. 2 possess a different type of self regulated learning than regular, non-working students. The business of work sometimes make it difficult for students in the employee class to manage their time between college, study, work, and rest, which can affect study result or academic achievement. There is also a possibility of lack of motivation to finish study and, as a result, study result can also suffer. Unlike students in the employee class, regular college students have more time to study, so their self regulating is only used for learning. But, regular college students also face their own difficulties. In their daily lives, college students, as subjects who learn in college, obviously are never free from studying activities, many assignments from lecturers, and other outside activities such as extracurricular or college organizations. This makes it important for regular college students to possess good self regulating and time management skills to allow all their activities to run smoothly and to maintain their academic achievement. Self regulated learning refers to a study activity which mostly happens from a student's own cognitive, feeling, strategy, and behavior with a purpose to achieve a goal (Schunk and Zimmerman, 1998 in Mukhid, 2008). Metacognitively active means that a college student as learner (self regulated learner) plans, organizes, trains, monitors, and evaluates oneself during the study process. Motivationally active means that a college student, in one's study process feels that one is competent, possessing self efficacy, and autonomy. While being behaviorally active means a college student's ability to select, arrange, and create one's own environment to support optimal learning. As college students who are demanded to actively and independently learn, self regulated learning is very necessary. Latipah (2010) discovered that self regulated learning can positively affect 
study achievement. Kirana (2017) also found that Self-regulated Learning skill is effective in reducing academic procrastination of students - According to Aimah and Afidah (2014), college students have yet to be able to perform self regulated learning well. In general, their studying activity are usually performed without a good planning of what activities they're going to perform, no monitoring and evaluation of thir own study result, whether or not it has reached a certain target. Coupled with the increase of current digital advancement, it causes college students to be more likely to be distracted from their study goal, such as the possibility of game addiction, social media addiction, gadget addiction, internet addiction, or other forms of addiction. This makes it important to see a depiction of self regulated learning on college students, especially the differences between self regulated learning capability on non-working college students and working college students at the Faculty of Psychology, X University.

\section{METHOD}

Utilizing qualitative research method, the research type utilized in this research is comparative research, which is utilized to discover the similarities and differences in self regulated learning capability on working and non-working college students. The samples in this research are active college students enrolled in Mercu Buana University's Faculty of Psychology, with a total of 86 non-working college students and 91 working college students. The sample collection technique utilized in this research is non-probability sampling, a sample collection technique that doesn't give equal opportunity for all population to be part of the sample (Sugiyono, 2013). The technique utilized is incidental sampling technique, which is a technique which allows anyone who by chance meet the researcher and is deemed to fit the research criteria can be used as sample (Sugiyono, 2013).

\section{RESULTS AND DISCUSSIONS}

From the calculation of this research, it was found that there is a significant difference in the average empiric score of self regulated learning capability between non-working and working college students. The average self regulated learning capability score of nonworking college students are higher than working college students, with an average score of 112.42 for non-working college students, compared to the average self regulated learning capability score of working college students, which is 109.64. This result corresponds with the research of Daulay and Rola (2009) which 
states that there is a difference in self regulated learning capability between working college students and non-working college students. In their opinion, working college students have low motivation in achieving study success because they consider that working college students are already capable of earning a living and view college classes merely as an obligation to be able to graduate and earn a diploma.

In this research, non-working college students have a higher average score compared with the average score of working college students. Based on the categorization result of self regulated learning capability on nonworking college students shows that most nonworking college students are at a high level of self regulated learning (56.5\%). Zimmerman (1989) stated that the difference in self regulated learning is affected by a number of factors, which are (a) individual factors, consisting of 4 points; individual knowledge, level of an individual's cognitive ability, goal, and affection, (b) behavioral factor, and (c) environmental factor. The more, and more varied, knowledge an individual possess, it will be more helpful for one's management ability. The more optimal effort an individual exert in managing and organizing an activity will improve the individual's regulation capability.
Self regulated learning possesses three aspects, or dimensions, that are also indicators of its levels, which are metacognitive dimention, motivation dimention, and behavior dimention. Based on the metacognitive dimension, the percentage non-working college students who are at a high level is $89.5 \%$, while the percentage of working college students who are at a high level is $92.44 \%$. This research discovered that the average of working college students' metacognitive is higher than that of nonworking college students'. Respondents who are working college students have a much higher age level than non-working college students; if this is connected with the fact that working college students have a higher metacognitive ability than non-working college students, then this result corresponds with the result of the research performed by Veenman and Spaans (2005), which concluded that metacognitive ability will continue to develop with age. Aside from that, working college students have more activities and more complex goals than non-working college students. Working college students are demanded to be able to finish multiple different tasks at once and evaluate the result of their works. Based on the interview with respondents who are working college students, researcher found that working 
college students possess the ability to think about more than one factor or problem; they are also capable of evaluating their study, such as finding a suitable memorizing technique, and elaborating the knowledge they earned in their social working environment. As a result, working college students have better ability in monitoring, organizing, and evaluating goals and study results.

For motivational dimension, nonworking college students' score are higher than that of working college students. Nonworking college students who are at a high level is $100 \%, 2.6 \%$ higher than the percentage of working college students. Motivation in self regulated learning is a driving factor within the individual which includes perception towards self efication and autonomy competence that an individual possess in the study activity. According to Zimmerman (1989 in Maftuhah, 2012), individual with a good motivation is an individual who have interest in the task given and tries to be diligent in learning by selecting, arranging, and creating a favorable environment for study. This research shows that the motivation of working college students are slightly lower than the motivation of nonworking college students. It seems that working college students' metacognitive ability doesn't greatly affect their study motivation. According to Daulay and Rola (2009), this happens because working college students tend to be less motivated to achieve their academic goals. This is different with non-working college students, who have a lot of time to study and work on their assignments at home, so that they are more motivated to achieve their academic goals. This result matches the result of the researcher's interview with one non-working college student, who stated that non-working college students motivate themselves to earn high academic achievement, and to create a study environment which they like, such as discussing and studying with their friends.

For behavioral dimension, working college students are, on average, at a medium level, with $70.59 \%$ of the sample, meanwhile the number for non-working college students are $53.04 \%$. In this dimension, an individual's effort to manage time, to regulate the effort, to make plans on when to study, and also to seek for help. In this dimension, working college students have different burdens and responsibilities compared to the non-working college students. This result corresponds with the result of interviews that the researcher performed with 3 working students of Mercu Buana University's Faculty of Psychology. 
From the interview with the aforementioned respondents, it was discovered that two of the respondents found it difficult to manage time between study, college, work, rest, and other activities. Respondents often had to skip class because of the amount of work they have to handle or because of out-of town assignments. Sometimes, respondents work on their college assignments in the middle of work hours, and it is not uncommon for the respondents to pull an all-nighter just to be able to finish their college assignments. Aside from that, working college students don't only have a singular goal to succeed in their academic life; they also have other goals such as personal success, career success, and, in the case of married college students, success in family life. This factorcauses working college students to possess motivation that are not strictly oriented towards success in study. In regards to behavioral factor, working college students have more activities compared to non-working college students. Some working college students also work full time, and this can affect their physical and mental condition. This is crucial, because physical exhaustion can affect an individual's affection and cognition in managing self regulated learning strategy. Regarding the dimension level of self regulated learning, working college students possess a higher cognitive dimension than non-working college students by $2.88 \%$. For the level of motivational dimension, non-working college students are $2.6 \%$ higher than working college students. Meanwhile, for the level of behavioral dimension, non-working college students are also higher than working college students by $17.55 \%$. This result suits the result of an interview with non-working college students from Mercu Buana University's Faculty of Psychology, who stated that they have a sufficient amount of time in their hands, which enable them to manage it for their study or to work on assignments. They can also choose other activities that don't interfere with their study activity in college. Aside from that, by having many friends, they can also easily discuss about their assignments and can choose a comfortable environment that can support their study activities.

Result from additional research has also shown that there is no significant difference of self regulated learning level between male and female college students who are enrolled in Mercu Buana University's Faculty of Psychology. This means that both male and female are capable of self regulated learning, that they are both able to manage their study independently by involving cognitive, motivation, and behavior. With that being said, the mean empiric result 
shows that the average score for female college students are higher (111.58) than the average score for male students (109.55). This result matches the result of a research performed by Bidjerano (2005), titled Gender Differences in Self-Regulated Learning, which stated that there is no significant difference between male and female in regards to self regulated learning capability.

\section{CONCLUSSION}

From this research, it can be inferred that the self regulated learning capability of non-working college students is higher than the self regulated learning capability of working college students. Although the level of metacognitive and behavioral dimension in working college students are highter compared to non-working college students, the level of motivational dimension in non-working college students is higher than that of working college students. In terms of self regulated learning, motivation is a driving factor from within the individual which includes perception towards self efficacy and autonomous competence that the individual possess in study activity. It seems that working college students' ability to regulate their behavioural and metacognitive dimension doesn't have much impact on their study motivation in this digital age.

\section{SUGGESTIONS}

Based on the result of this research, the researcher are advocating these following suggestions:

1. Suggestion for college students

The result of this research shows that both working and non-working college students possess self regulated learning capability, but the level of self regulated learning capability is different. Non-working college students have a better level of self regulated learning capability, but regarding metacognitive dimension, nonworking college students' level is lower than that of working college students. The researcher suggests that non-working college students to improve their metacognitive aspect by practicing good rehearsal technique, more indepth elaboration, planning, monitoring, and evaluating study result.

On the other hand, the motivational and behavioral dimensions of working college students also need improvement. The researcher suggests that working college students improve their motivation which can be done through coaching, where college students approach and interact with more successful people to increase their autonomous feeling and to become more 
competent in study. Furthermore, to improve the behavioral dimension, working college students are expected to train and familiarize themselves with good time management, creating a more supportive environment for their study activity, and also to take advantage of friends or lecturers to support their effort in improving their self regulated learning capability.

\section{Suggestion for colleges}

Colleges are suggested to provide training to improve self regulated learning capability, such as time management training and training for improving motivation to achieve study success for working college students, and problem solving training for non-working college students.

\section{Suggestion for further researches}

The researcher suggests that further researches add other variables related to self regulated learning, and also to examine the differences in self regulated learning based on other aspects.

\section{BIBLIOGRAPHY}

Ahmadi, F. (2012, Juli 18). Peran dan Fungsi Guru.Kompasiana.com.http://edukasi. kompasiana.com/2012/ 07/18/ perandan-fungsi-guru.

Alwi, H. (2005) . Kamus Besar Bahasa Indonesia.
Jakarta, INA: Balai Pustaka.

Center for Advanced Human Resource Studies. (2010). Work - Family Conflict Not Just a Woman's Issue: Helping all employees find work life balace.http://www.ilr. cornell.edu/cahrs/hrSpectrum/May11Livingston-Work-Family-ConflictResearchLink.html.

Cheung and Tang. (2009). Quality of Work Life as a Mediator Between Emotional Labor and Work Family Interference. J Bus Psychol, 24:245-255 doi:10.1007/s10869009-9103-7.

Fatimah, Dwi. (2014). Perbedaan Stres Pada Ibu Rumah Tangga Yang Bekerja Dengan Ibu Rumah Tangga Yang Tidak Bekerja di Kelurahan Labuh Baru Barat. Universitas Islam Negri Sultan Syarif Khasim:Skripsi diterbitkan.

Fazriyati, W. (2011, November 12). Ayah bukan Hanya Figuran di Keluarga. Kompas.com.http://female.kompas.com/ $\mathrm{read} / 2011 / 11 / 12 / 09365696 /$ Ayah.bukan . Hanya.Figuran.di.Keluarga.

Gray, T.(n.d).Fatherhood.http://www.f ocusonthefamily.com/parenting/ parenting_roles/fatherhood.aspx.

Greenhaus, J. H., \& Beutell, N. J. (1985). Sources of conflict between work and family roles. 
Academy of Management Review,10, 76-

88.

Hidayati, Kaloeti, \& Karyono (2011). Peran Ayah dalam Pengasuhan Anak. Jurnal Psikologi Undip, 9(1), 1-10. ejournal. undip.ac.id/index.php/psikologi/.../2525.

Judge, T.A., Joyce, E.B., Carl,J.T., and Gregory, K.P. (2001).The Job Satisfaction-Job Performance Relationship: A Qualitative and Quantitative Review.Psychological Bulletin, Vol. 127. No. 3. 376-407.

Khan et al. (2012).Work-Family Conflict And Burnout Among Lecturers Of Public Sector Colleges. Pakistan Journal of Psychology,43(2), 93-107.

Kirana, A., Sahrani, R and Hastuti, R. (2016). Efektivitas Pelatihan Self-Regulated Learning dalam Mereduksi Prokrastinasi Akademik Siswa (Studi pada Siswa SMPN "X" di Jakarta Barat). Provitae Jurnal Psikologi Pendidikan, 7 (1), 20 - 36

Lamana, M.A., Riedman, A., \& Strahm, A. (2012). Mariages, Family \& Relationship : Making choices in a diverse society (11th ed.). Belmont, CA: Woodsworth Engage Learning.

Lamb, M.E. (Ed.). (2010). The Role of the father in child development (5th Ed). Hoboken, NJ: John Wiley \& Sons.

Murtiningrum, Arfina.(2005). Analisis

Pengaruh Konflik Pekerjaan Keluarga

Terhadap Stress Kerja dengan Dukungan Sosial Sebagai Variabel Moderasi. Universitas Diponegro Semarang :Tesis tidak diterbitkan.

Myers,D.G. (2013). Social Psychology (11th Ed.). New York, NY: Mc Graww-Hill.

Netemeyer, R., Boles, J. \& McMurrian, R. (1996). Development and Validation of Work- Family Conflict and FamilyWork Conflict Scales, Journal of Applied Psychology, 81(4), 400-410.

Patton, M. (1990). Qualitative evaluation and research methods(pp. 169-186). Beverly Hills, CA:Sage.

Poerwandari, E. K. 2005. Pendekatan kualitatif untuk penelitian perilaku manusia (edisi. Ketiga). Depok: LPSP3 Fakultas Psikologi Universitas Indonesia.

Poerwandari, K. (2007). Pendekatan kualitatif untuk penelitian perilaku manusia. Jakarta, INA:LPSP3 Fakultas Psikologi Universitas Indonesia.

Poerwandari, K.E. 2011. Pendekatan Kualitatif dalam Penelitian Psikologi. Depok: LPSP3. Fakultas Psikologi Indonesia. 
Rahman, Abdul. (2015, Juni 18). Beban

Berat Seorang Dosen.Kompasiana. com.http://www.kompasiana.com/ abdulazizrahman/beban-berat-seorangdosen.

Rani, A. M. P. (2011). Pengaruh dukungan sosial terhadap konflik kerja keluarga dan peningkatan kualitas kehidupan kerja keluarga.Universitas Atmajaya Yogyakarta: Skripsi Tidak diterbitkan.

Reddick, R. J., Rochlen, A. B., Grasso, J. R., Reilly, E. P., \& Spikes, D. D. (2012). Academic fathers pursuing tenure: a qualitative study of work - family conflict , coping strategies and departmental culture. Psychology of Men and Masculinity, 13(1), 1-15. doi: 10.1037 /a0023206.

Satori dan Komariah. (2010). Metodologi Penelitian Kualitatif. Bandung : Alfabeta. Sarafino, E. P. \& Smith. T.W.(2011). Health Psychology: Biopsychosocial Interactions (7th Ed.).New York, NY: John Wiley \& Sons.

Soeharto, T. N.E.P. (2008). Nilai positif Pekerjaan Keluarga: Tinjauan teori. Jurnal Insight, P.1-9.

Slameto(2002). Peranan Ayah dalam Pendidikan Anak dan Hubungannya dengan Prestasi
Belajarnya. http://re-searchengines.com/ slameto2.html.

Spector, P. E. (2012). Industrial and Organizational Psychology Research and Practice (60nd ed). New York: Jhon Wily \& Sons, Inc.

Stewart, Charles. J \& Cash, W.B,. (2000). Interviewing: Principles and practices. USA: McGraw Hill Company.

Stronge, J.H. (2007) . Qualities of effective teachers (2nd ed) . Alexandria, VA: Association for Supervision and Curriculum development.

Wagiran dan Widodo.(2005). Upaya guru dalam optimalisasi pembelajaran ditinjau dari heterogenitas karakteristk mahasiswa http://staff.uny.ac.id/.../upaya\%20\%20 Penelitian.

Yang, N; Chen, C C; Zou Y. (2000). Sources of Work-Family Conflict : A Sino-US Comparison of The Effects of Work and Family Demands. Academy Management Journal, Vol.43, No.1, p:113-123.

Yuniardi, M.S. ( 2009). Penerimaan Remaja Laki-Laki dengan Perilaku Antisosial terhadap Peran ayahnya dalam Keluarga. http:// research-report.umm.ac.id/index. php/research-report/article/view/244 